\title{
Prue Taylor
}

\section{Governing the

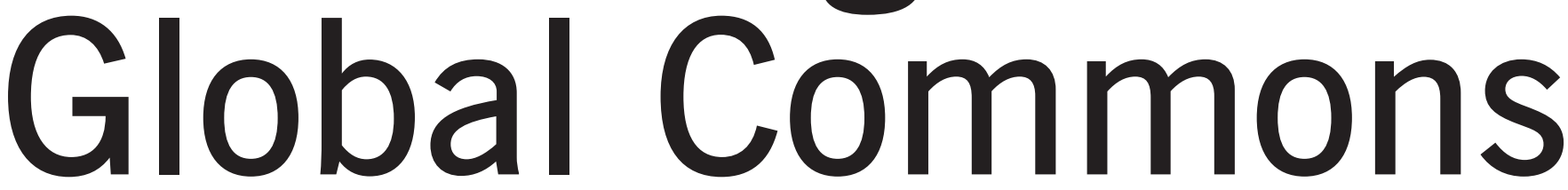 \\ an ethical-legal framework}

We stand at a critical moment in Earth's history, a time when humanity must choose its future. As the world becomes increasingly interdependent and fragile, the future at once holds great peril and great promise. To move forward we must recognise in the midst of a magnificent diversity of cultures we are one human family and one Earth community with a common destiny.

- preamble, Earth Charter

Governance of the Earth's global ecological commons creates unprecedented challenges for humanity. Our traditional Westphalian state system was not designed to respond to these global challenges and thus far it has failed to transform. Climate change is the current headline issue; 30 years on and we still swing between hope and despair about our collective ability to radically reduce greenhouse gas emissions. Related

Prue Taylor teaches environmental and planning law at the School of Architecture and Planning, University of Auckland, and is Deputy Director of the New Zealand Centre for Environmental Law and a member of the IUCN World Commission on Environmental Law. She is a board member of the New Zealand Centre for Global Studies. issues are beginning to vie for our response: ocean acidification, mass species extinction, land use change and freshwater scarcity (Steffen, 2016, p.23). The emerging field of Earth system science demonstrates that the complex integrated system, upon which all 
humanity and all life depends, is imperilled. The cumulative impact of human activities is the destabilising force (ibid., 2016). Tackling climate change is just the beginning of our endeavours to live within the life-supporting capacity of the Earth system.

This article considers how humanity might respond to the global ecological challenge from the perspective of ethics and law. ${ }^{1}$ The specific focus is the emergence of communitarian values and their articulation in international environmental law. It will be argued that there are tentative signs of communitarian values influencing legal development. These represent small cracks in the are not new. For decades the literature on global values has developed alongside that of environmental or ecological ethics. Learning from the horrors of the Second World War, leading thinkers understood that human security resided in understanding the interdependence of ecological protection and social equity. The draft World Constitution of 1948 was created with this concern in mind. It provides that the common good should have priority over private interests in respect of the commons (i.e. the four elements of life). The 1987 World Commission on Environment and Development (WCED) called for states to create a Universal Declaration

\section{The Earth Charter itself is a laudable achievement, but it is the process of its creation that is more important and the source of its legitimacy.}

edifice of state-centred international law. For the most part we continue to use an international legal system which prioritises and weights rights and obligations 'within a closed compartment of individual state self-interest'. ${ }^{2}$ There is much for an emergent global community to do, across spatial and temporal scales of growing complexity.

\section{A shared ethical vision}

The preceding article considered the transformation of states into 'trustees' with fiduciary obligations owed to all human beings. These obligations would be fulfilled both internally and externally for the common (ecological) good. Foundational to such proposals is our ability as humans to develop and share a common set of values that can connect, inspire and guide us. From these basic values, implementing principles can be developed, which can then be articulated in policy and law.

In the context of sustainable development, acknowledgement of the need for a shared ethical vision to guide policy and law, and efforts to achieve it, sustainable future. Officially launched at the Peace Palace in The Hague in June 2000, the charter articulates the values of care, respect and responsibility for each other and the integrity of planetary systems (part I), and includes a number of supporting principles designed to serve as common standards for guiding and assessing the conduct of individuals, organisations, businesses and governments.

The Earth Charter itself is a laudable achievement, but it is the process of its creation that is more important and the source of its legitimacy. It is the product of a decade-long cross-cultural dialogue on common goals and shared values. The drafting was the result of the most open and participatory consultation process every associated with the writing of an international document. Hundreds of organisations and thousands of individuals participated, ensuring that the charter reflects the influence of many intellectual sources, social movements, religious and philosophical traditions and new world views shaped by many disciplines, including science, cosmology and ecology (Rockefeller, 2008). As a result of this process (or 'ethical dialogue'), the people achieved what states could not. It is for good reason that the preamble begins: 'we, the peoples of the Earth'.

As with many international documents, the launch marks the starting point for the real work to come. In the case of the Earth Charter, the task is to build a stronger global society which includes governments, businesses, organisations, transnational institutions and individuals, acting together and consistently with global interdependence and universal responsibility. The charter can contribute to this task through its content (universal values), scope (cross-cultural acceptance) and support (endorsement and membership of the Earth Charter Initiative).

More significantly, it is a powerful tool for education and further ethical dialogue. It requires us to '[re]-ask and re-explore its fundamental animating questions. What are our deepest responsibilities to Earth and its inhabitants, human and other? And why?' (Donnelly, 2004). In 
this sense it is a living document, open for further evolution. It does not deny the immense difficulties of finding and maintaining unity: 'Life often involves tensions between important values. This can mean difficult choices. However, we must find ways to harmonize diversity with unity, the exercise of freedom with the common good, short-term objectives with long-term goals' (Earth Charter Institute, 2000, 'The way forward').

For all its promise and achievements to date, an important critique has emerged. A core member of the drafting team argues that the charter, and the social movement that it has created, have thus far failed to adequately challenge the 'contemporary unjust, unsustainable and violent international order' (Engel, 2014, p.xvi). The charter must do more than offer alternative ethical principles. Related to this critique is the reality that the charter has not, to date, greatly influenced the actions of states or development of international environmental law. It has not yet been the subject of a UN General Assembly resolution, although this has been a goal for many years. On the other hand, it has been officially endorsed by member states (and organisations) through resolutions of UNESCO and the International Union for Conservation of Nature (IUCN).

In a soft-law context, the charter has greatly informed the IUCN draft Covenant on Environment and Development, although this document also requires further endorsement by states. The more recent draft World Declaration on the Environmental Rule of Law, moreover, draws heavily upon the charter, with principle 1 articulating a universal responsibility to care for nature, independent of its instrumental values. The charter has also had a significant influence on the work of many academics (Bosselmann and Engel, 2010), and many of its more developed principles are being applied in national courts. Its 'hard-law' character deserves better acknowledgement (Robinson, 2010).

In the more specific context of climate change, Pope Francis's encyclical Laudato Si' (On Care for Our Common Home) called the world to action ahead of the Paris climate change negotiations in 2015. Embracing the Franciscan tradition, it acknowledges the ecological crisis, confronting the common home of humanity and all life, to be a great moral challenge. It calls on every person on the planet to engage in a new and inclusive dialogue of ecological responsibility. The essential message of Laudato Si is reflected in a number of faith and interfaith declarations on climate change. ${ }^{3}$ Of equal interest was the Call to Conscience declaration, intended as a reminder to state negotiators (ahead of the Paris negotiations) that policy and law are not value free. ${ }^{4}$
The documents discussed above differ in their scope, focus and source of legitimacy, but they share the aim of articulating communitarian values of universal responsibility for the common good.

\section{Ethics and international environmental law}

What do the above expressions of values have to do with the law? There are different views. One view is nothing or very little; international law is and remains the near exclusive domain of states. A sovereign self-interest and competitive rights focus dominates, as does the principle

\section{Co-operation between the international community of states remains 'thin': that is, its central reference point remains the individual and collective interests and goals of states.}

Similarly, the international scientific community has also become engaged in ethical issues. The Intergovernmental Panel on Climate Change (IPCC) fifth assessment report, in its Working Group III report, included two chapters referencing ethical issues (IPCC, 2014, chs 3 and 4). Although more focused on the burden-sharing aspects of climate change, Working Group III noted that there is a basic set of shared ethical premises and precedents that apply to climate change which put limits on plausible interpretations of equity and fairness in the burden-sharing context (ch.4, p.49). The four key dimensions of equity were identified as: responsibility, capacity, equality and the right to sustainable development. The working group also noted that it is morally proper to allocate burdens according to ethical principles and that the eventual effectiveness of a collective action regime may depend on the ability to do so (ch.4, pp.16-17). Climate change policy that is too narrowly focused on traditional utilitarian or costbenefit analysis neglects critical ethical concerns (ch.4, p.8). of reciprocity. Co-operation between the international community of states remains 'thin': that is, its central reference point remains the individual and collective interests and goals of states. The law does not yet require states to prioritise and act consistently with the 'greater interests of humanity and planetary welfare' (Brunnée, 2008, p.554). ${ }^{5}$

An alternative view is that values have everything to do with international law. As a previous article in this issue has noted, different schools of international relations theory draw upon arguments for, and evidence of, common normative positions. Natural law and humanitarian law also draw upon globally identifiable values. In a planetary ecological context we can add the reality that we are undermining the basis of our own existence and that of others. The articulation of shared values, in law, takes the human response beyond that of mere necessity. For this reason, there is a motivation and need to identify a global set of values and interests providing a basis for future law and minimum standards for environmental 
protection, in the absence of treaty law. This can be characterised as an effort to articulate a form of ordre de public, in a similar manner to the Martens Clause which became the basis for international humanitarian law (Shelton, 2009).

This effort to develop law around a conception of 'common interests' different from those of states alone does not deny the relevance of national self-interest. Rather, it recognises that in the long term they can only be protected within

commons? This section considers some examples from both existing and emerging law.

The 'common heritage of humankind' is considered one of the strongest articulations of international environmental trusteeship (Birnie et al., 2009, p.198). Its ethical foundations are found in African customary law, Asian non-theist traditions and Roman law, as well as Christian theology and Islamic law. At its core is the notion of sustaining

\section{... the status of the concept 'implies that [the global environment] can no longer be considered solely within the domestic jurisdiction of States due to its global importance and consequences for all ...'}

the framework of a stable legal regime of close co-operation for the benefit of all. Nor should this effort be dismissed as illusionary utopianism. Prominent international jurists have argued that it is the legitimate role of legal scholars to actively pursue a utopian agenda if an appropriate process is followed (Peters, 2013, p.548). Cassese explores this process and describes it as critical positivism (Cassese, 2011, p.258). It involves an ethical analysis that recognises the importance of values and uses them to both critique existing law and argue persuasively about what the law 'ought' to be and how to get there (Peters, 2013). Cassese's critical positivism provides a strategy for weaving humanism into legal reasoning (ibid., p.552). However, for the time being power to resolve the problems of the world community remains in the hands of politicians, diplomats and military leaders. Therefore, scholars may 'suggest ideas and advance solutions, without harbouring too many illusions' (Cassese, 2011, p.271).

\section{Values, law and the global ecological commons}

What signs are there of communitarian values influencing legal development applicable to the global ecological the basis or foundations of life, as a precious gift of inheritance (patrimony), for the benefit of all. It expresses concern and responsibility for the 'other' that encompasses both human interactions (between present and future generations) and the human-nature relationship. Ultimately it is about collective human responsibility for the ecological commons (Mann Borgese, 1986, ch.6).

While there is contention about some of its legal elements, two of the least contentious are intra and intergenerational equity and environmental protection (Wolfrum, 2008). A recent opinion of the International Tribunal for the Law of the Sea confirmed (in the deep seabed mining context) that it required states to exercise the highest degree of environmental protection. Further, the ultimate reference point was the interests of present and future generations and not states (ITLOS, 2011). While holding much promise, the 'common heritage' concept proved too controversial for use in treaties on climate change and biological diversity. However, current negotiations on a regime for biodiversity in areas beyond national jurisdiction demonstrate that many states still support the concept as a guiding principle (Long and Rodríguez Chaves, 2015). As with the deep seabed, environmental protection would need to be prioritised over resource use (i.e. marine genetic resources) to ensure that the objectives of a common heritage regime are met. Aside from treaty practice, the concept is closely related to the emergence of the principle of 'common but differentiated responsibility and respective capacities' and environmental human rights (World Declaration on the Environmental Rule of Law, principle 2). It also continues to inspire and guide the efforts of legal academics to find solutions to the current failures of global governance and the ongoing degradation of the global ecological commons (Weston and Bollier, 2013; Magalhães et al., 2016).

In a related treaty context, the 1972 UNESCO Convention Concerning the Protection of World Cultural and Natural Heritage (UNESCO, 1972) provides that features of universal value to mankind should be subject to legal protection for the benefit of present and future generations. It is the duty of the international community as a whole to ensure protection, not just of states that exercise territorial jurisdiction. The treaty qualifies and restricts exercises of sovereignty for the benefit of all humanity. It is currently limited in scope to heritage within national jurisdiction. However, there is a novel proposal to apply the universal value of mankind concept to parts of the high seas, an acknowledged international commons, beyond the jurisdiction of any state (Freestone et al., 2016). This may be useful for future efforts to find a co-ordinating concept to guide the development of marine protected areas within the high seas.

Returning to legal concepts, the 'common concern of humankind' is of potential importance. Adopted as an alternative to, but not substitute for, 'common heritage', it is used in the preambles of both the UN Framework Convention on Climate Change (1992) and the UN Convention on Biological Diversity (1992). There is a general view that the specific legal implications of the 'common concern of humankind' should be drawn from the treaty regimes in which it appears (Brunnée, 2008). A narrow interpretation in the 
context of climate change suggests that its role does not extend beyond the provisions of common but differentiated responsibilities and respective capacities (Soltau, 2016). Furthermore, the bottomup approach to setting nationally determined contributions (in the 2015 Paris Agreement) may have weakened much of the concept's potential.

Climate change aside, the potential for the 'common concern' concept is articulated by the IUCN draft Covenant on Environmental and Development (IUCN Environmental Law Programme, 2015). It states that the Earth's biosphere or global environment as a whole should be recognised as a common concern. Article 3 provides that: 'The global environment is a common concern of humanity and under the protection of the principles of international law, the dictates of public conscience and the fundamental values of humanity.' The commentary notes that: ' $\mathrm{t}$ ] he interdependence of the world's ecological systems and the severity of current environmental problems call for global solutions ..., thereby justifying designation ... as a matter of "common concern" (p.45). Furthermore, the status of the concept 'implies that [the global environment] can no longer be considered solely within the domestic jurisdiction of States due to its global importance and consequences for all. It also expresses a shift in classical treaty-making notions of reciprocity and material advantage [to States], to action in the long term interests of humanity' (ibid., emphasis added). As previously noted, the draft covenant does not yet have the endorsement of states as an international framework convention. Nevertheless, it is intended to be a codification of existing international environmental law.

A further area of international environmental law development reflective of communitarian ethics is the emergence of environmental human rights, both in a collective (Westra, 2011) and individual context (Shelton, 2011, pp.385-473). Although not yet the subject of a legally binding international agreement, national developments may clear the way for this to happen in the near future. A survey of national constitutions revealed that some 125 contain environmental norms, 92 of which explicitly recognised a human right to the environment (Boyd, 2012, p.72). ${ }^{6}$ No other human right has achieved this level of recognition in such a short timeframe (Law and Versteeg, 2011). The UN Declaration on the Rights of Indigenous Peoples is unequivocal on the matter of indigenous rights and the environment: article 25 acknowledges the importance of spiritual relationships and responsibilities and article 29 provides for the right to protection and conservation of the environment and productive capacities of land and resources.

In a transnational context, domestic different approach to global commons management, with the objective of creating new institutional and legal structures and forms fit for contemporary ecological and social challenges (Bollier, 2014). It places overarching emphasis on providing for collective benefit, as a necessary precondition for providing for the individual prosperity of all humanity (present and future). Commons scholarship reminds us that alternative (and potentially transformative) forms of governance and law are possible, which return authority and responsibility to communities of people and do not swing

\section{A further thread of emergent communitarian values within international environmental law can be found in the growing literature around global environmental constitutionalism.}

legal action on global ecological issues (in the absence of legal standing before international courts) is reflective of emerging communitarian values. Climate change litigation, in the interests of future generations, is beginning to proliferate (see, for example, the Urgenda case in the Netherlands). ${ }^{7}$ More specifically, the 1998 Aarhus Convention on access to information, public participation in decision-making and access to justice in environmental matters facilitates transnational review of a state's actions through its compliance committee. This innovation is a strong acknowledgement of the importance of national oversight and the interconnection of ecological systems.

The implementation of communitarian values in international law is also closely related to the reemergent commons movement. Drawing on the work of Nobel Prize winner Elinor Ostrom, and the acknowledged limitations of international law (Tomuschat, 2011; Hafner, 2011), commons scholarship proposes a very between the poles of private versus public or result in a slide back to the tragedy of the (open access) commons (Mattei, 2012). Moreover, commons regimes provide for a diverse range of values, often relational in character, beyond dominant economic exchange values. Both the critique and the solutions provided by commons scholarship will be significant for the redesign of governance and law to meet global ecological decline (Weston and Bollier, 2013; Westra, 2011).

A further thread of emergent communitarian values within international environmental law can be found in the growing literature around global environmental constitutionalism. In a recent article, Bosselmann considers the evidence for an emerging constituting principle and finds that the argument for sustainability 'as a constitutional principle in national and international law is strong and deserves further investigation' (Bosselmann, 2015, p.182). Ultimately, the purpose of global environmental constitutionalism is to shift environmental concerns from the 
periphery to the centre of constitutions, laws and governance.

This section has considered signs of communitarian values influencing legal development applicable to the global ecological commons. Viewed in isolation, each of these developments can be seen as of limited impact in the realm of realpolitik. Indeed, powerful states have largely resisted many developments in defence of their sovereignty. However, taken together the whole suggests a building trend towards the transformation of law and governance for the global ecological commons. To deliver on this transformation, humanity must also create a global polity capable of working for the global collective benefit. In this regard, climate change is viewed as a significant opportunity for building global citizenship (German Advisory Council on Global Change, 2014) and a much-needed global social movement (Dunlap and Brulle, 2015). Ultimately, this could, at a normative level, contribute to 'recouping the original promise of the environmental movement, that is the conceptualization and the legal treatment of the natural environment as a [common good] to be administered in the interest of all and of the generations to come' (Francioni, 2012, p.455, emphasis added).

\section{Conclusion}

The Earth Charter text ends with a section entitled 'The way forward'. This resides in deepening and expanding the global ethical dialogue, developing partnerships between government, civil society and business, and nation states renewing their commitment to the United Nations and fulfilling their obligations under existing international agreements. It also resides in the implementation of ethical principles in law.

It is true that states control lawmaking, but academics have a vital role to play in overcoming the positivist tendencies of international law. They can articulate fundamental norms and associated legal principles, consistent with their realisation. In the words of Arvid Pardo, founder of the common heritage concept, it is an 'appropriate function of lawyers to comprehend the reality that surrounds them. Equipped with such an understanding they are entitled to propose legal principles designed to meet to the maximum extent possible - taking into account all the challenges of the ecological age - the needs, wants, interests and values of individuals and of society at large ...' (Pardo and Christol, 1983, p.658)

Ten years later Pardo added: '[i]t will be up to all of us ... to open deeper and wider cracks in traditional international law until, in the eternal cycle, a new global order emerges from the ruins of the old, better to serve all humanity' (Pardo, 1993, p.69).

\footnotetext{
1 Parts of this article are based on previously published work on the common heritage of mankind and the commons: see, for example, Taylor (2016).

2 Case Concerning the Gabcikovo-Nagymaros Project (Hungary v. Slovakia), [1997] I.C.J. Rep. 7, separate opinion of vice president Weeramantry, C(c).

3 From Buddhist and Islamic religious traditions.

4 See also UNESCO (2015); Brown (2013); Gardiner (2011).

5 Referencing Judge Weeramantry's dissenting opinion in Dam case (see note 2 ).

6 See also the concept of ecological human rights: Taylor (2011).

7 http://www.urgenda.nl/en/climate-case/.
}

\section{References}

1992 Convention on Biological Diversity, International Legal Materials, 31,818

Aarhus 'Convention on access to information, public participation in decision-making and access to justice in environmental matters', Aarhus, Denmark, 25 June 1998, https://www.unece.org/fileadmin/ DAM/env/pp/documents/cep43e.pdf

Birnie, B. et al. (eds) (2009) International Law and the Environment, Oxford: Oxford University Press

Bollier, D. (2014) Think Like a Commoner: a short introduction to the life of the commons, British Columbia: New Society Publishers

Bosselmann, K. (2015) 'Global environmental constitutionalism: mapping the terrain', Widener Law Review, 21 (2), pp.171-85

Bosselmann, K. and J.R. Engel (eds) (2010) The Earth Charter: a framework for global governance, Amsterdam: KIT Publishers

Boyd, D.R. (2012) The Environmental Rights Revolution: a global study of constitutions, human rights, and the environment, Vancouver: UBC Press

Brown, D.A. (2013) Climate Change Ethics: navigating the perfect moral storm, Oxon; New York: Routledge

Brunnée, J. (2008) 'Common areas, common heritage, and common concern', in D. Bodansky, J. Brunnée and E. Hey (eds), The Oxford Handbook of International Environmental Law, New York: Oxford University Press

Brunnée, J. (2011) 'The global climate regime: wither common concern?', in H.P. Hestermeyer, D. König, N. Matz-Lück, V. Röben, A. Seibert-Fohr, P.-T. Stoll and S. Vöneky (eds), Coexistence, Cooperation and Solidarity, Leiden: Brill Nijhoff
Dunlap, R. and R. Brulle (eds) (2015) Climate Change and Society: sociological perspectives, New York: Oxford University Press

Call to Conscience Declaration: why do I care?, http://www.whydoicare. org/en

Cassese, A. (ed.) (2011) Five Masters of International Law: conversations with R-J Dupuy, E. Jimenez de Arechaga, R. Jennings, L. Henkin and O. Schachter, Oxford: Hart Publishing

Donnelley, S. (2004) 'Chartering the Earth for life's odyssey', Worldviews: global religions, culture, and ecology, 8 (1), pp.93-100

Earth Charter Initiative (2000) 'The Earth Charter', http://earthcharter.org/ discover/the-earth-charter/

Engel, J.R. (2014) 'Summons to a new axial age: the promise, limits and future of the Earth Charter', in L. Westra and M. Vilela (eds), The Earth Charter, Ecological Integrity and Social Movements, Oxon; New York: Routledge, 2014

Francioni, F. (2012) 'Realism, utopia and the future of international environmental law', in A. Cassese (ed.), Realizing Utopia: the future of international law, Oxford: Oxford University Press

Freestone, D., D. Laffoley, F. Douvere and T. Badman (2016) World Heritage in the High Seas: an idea whose time has come, World Heritage Report 44, Paris: UNESCO, https://www.google.co.nz/search ?client $=$ safari\&rls $=$ en $\& q=$ World + Heritage + in + the + High + Seas $:+A$ $\mathrm{n}+$ Idea + Whose + Time + Has + Come $+($ UNESCO,+ July +2016$) \& i e=U$ TF-8\&oe $=U T F-8 \& g f e \_r d=c r \& e i=n \times 6 F W L D O I c z N 8 g f E-K a I B w$

Gardiner, S.M. (2011) A Perfect Moral Storm: the ethical tragedy of climate change, New York: Oxford University Press 
German Advisory Council on Global Change (2014) Climate Change as a World Citizen Movement, Berlin: WGBU

Hafner, G. (2011) 'The division of the commons? The myth of the commons: divide or perish', in H. Hestermeyer, N. Matz-Lück, A. Seibert-Fohr and A. Vöneky (eds), Law of the Sea in Dialogue, Berlin: Springer

Intergovernmental Panel on Climate Change (2014) Climate Change 2014: mitigation of climate change, Geneva: IPCC, https://www.ipcc. ch/report/ar5/wg3/

Islamic Climate Change Symposium (2015) 'Islamic declaration on global climate change', http://islamicclimatedeclaration.org/islamicdeclaration-on-global-climate-change/

ITLOS (2011) 'Advisory opinion of the Seabed Disputes Chamber of International Tribunal for the Law of the Sea on "Responsibilities and obligations of states sponsoring persons and entities with respect to activities in the area"', 11 February, https://www.itlos.org/fileadmin/ itlos/documents/cases/case_no_17/17_adv_op_010211_en.pdf

IUCN (2016) Draft World Declaration on the Environmental Rule of Law, http://iucnael2016.no/wp-content/uploads/2016/06/WORLDDECLARATION-ON-THE-ENVIRONMENTAL-RULE-OF-LAW-Near-FinalDraft-.pdf

IUCN Environmental Law Programme (2015) Draft Covenant on Environment and Development (5th edn), Bonn: IUCN, http:// cmsdata.iucn.org/downloads/eplp_31_rev_4.pdf

Law, D.S. and M. Versteeg (2011) 'The evolution and ideology of global constitutionalism', California Law Review, 99 (5)

Long, R. and M. Rodríguez Chaves (2015) 'Anatomy of a new international instrument for marine biodiversity beyond national jurisdiction', Environmental Liability, 23 (6), pp.213-29

Loy, D.R., B. Bodhi and J. Stanley (2015) 'The time to act is now: a Buddhist declaration on climate change', http://www.ecobuddhism. org/bcp/all_content/buddhist_declaration/

Magalhães, P., W. Steffen, K. Bosselmann, A. Aragão and V. SoromenhoMarques (eds) (2016), The Safe Operating Space Treaty: a new approach to managing our earth system, Newcastle upon Tyne: Cambridge Scholars Publishing

Mann Borgese, E. (1986) The Future of the Oceans: a report to the Club of Rome, Montreal: Random House

Mattei, U. (2012) 'First thoughts for a phenomenology of the commons', in D. Bollier and S. Helfrich (eds), The Wealth of the Commons: a world beyond market and state, Florence, Mass: Levellers Press

Pardo, A. (1993) 'The origins of the 1976 Malta Initiative', International Insights, 9 (2), pp.65-9

Pardo, A. and C.Q. Christol (1983) 'The common interest: tension between the whole and the parts', in R. St J. Macdonald and D.M. Johnston (eds). The Structure and Process of International Law: essays in legal philosophy, doctrine and theory, Leiden: Martinus Nijhoff

Peters, A. (2013) 'Realizing utopia as a scholarly endeavour', European Journal of International Law, 24 (2), pp.533-52

Pope Francis (2015) Encyclical Letter Laudato Si' of the Holy Father Francis On Care for Our Common Home, https://laudatosi.com/watch
Rockefeller, S. (2008) 'A short history of the Earth Charter initiative', in The Earth Charter Initiative Handbook, http://earthcharter.org/invent/ images/uploads/Handbook\%20ENG.pdf

Robinson, N.A. (2010) 'Foreword', in K. Bosselmann and J.R. Engel (eds), The Earth Charter: a framework for global governance, Amsterdam: KIT Publishers

Shelton, D. (2009) 'Common concern of humanity', Iustum Aequum Salutare, 2009 (1), pp.33-40

Shelton, D.L. (2011) Human Rights and the Environment, Edward Elgar Soltau, F. (2016) 'Common concern of humankind', in C.P. Carlarne, K. Gray and R. Tarasofsky (eds), The Oxford Handbook of International Climate Change Law, Oxford; New York: Oxford University Press

Steffen, W. (2016) 'The Planetary Boundaries Framework: defining a safe operating space for humanity', in P. Magalhães, W. Steffen, K. Bosselmann, A. Aragão and V. Soromenho-Marques (eds), The Safe Operating Space Treaty: a new approach to managing our earth system, Newcastle upon Tyne: Cambridge Scholars Publishing

Taylor, P.E. (2011) 'From environmental to ecological human rights: a new dynamic in international law?', in D.L. Shelton, Human Rights and the Environment, Edward Elgar

Taylor, P.E. (2016) 'The common heritage: constructive utopianism', in P. Magalhães, W. Steffen, K. Bosselmann, A. Aragão and V. SoromenhoMarques (eds), The Safe Operating Space Treaty: a new approach to managing our earth system, Newcastle upon Tyne: Cambridge Scholars Publishing

Tomuschat, C. (2011) 'Global warming and state responsibility', in H. Hestermeyer, N. Matz-Lück, A. Seibert-Fohr and A. Vöneky (eds), Law of the Sea in Dialogue, Berlin: Springer

UN (1992) United Nations Framework Convention on Climate Change, International Legal Materials, 31, 849

UN General Assembly (2007) United Nations Declaration on the Rights of Indigenous Peoples, http://www.ohchr.org/EN/Issues/IPeoples/Pages/ Declaration.aspx

UNESCO (1972) Convention Concerning the Protection of World Cultural and Natural Heritage, http://whc.unesco.org/en/conventiontext/

UNESCO (2015) Ethical Principles for Climate Change: adaptation and climate change, report of COMEST

UNFCCC (2015) Paris Agreement, adopted under the Framework Convention on Climate Change as an annex to a decision of the Conference of the Parties, http://unfccc.int/paris_agreement/ items/9485.php, accessed 22 September 2016

Weston, B.H. and D. Bollier (2013) Green Governance: Ecological Survival, Human Rights and the Law of the Commons, Cambridge: Cambridge University Press

Westra, L. (2011) Human Rights: the 'commons' and the collective, Vancouver: University of British Columbia Press

Wolfrum, R. (2008) 'Common heritage of mankind', in Max Planck Encyclopedia of Public International Law, retrieved from http://www. mpepil.com

World Beyond Borders (1948) 'Preliminary draft of a world constitution' (1947-1948)', http://www.worldbeyondborders.org/chicagodraft.htm 